\author{
Research Article \\ www.ijrap.net
}

\section{A PRELIMINARY PHYSICO-CHEMICAL ASSAY OF VAJIGANDHADI NIRUHA BASTI} \\ Surendra Kumar ${ }^{1 *}$, K.S. Patel ${ }^{2}$, A.B. Thakar ${ }^{3}$, C.R. Harisha ${ }^{4}$, V.J. Shukla ${ }^{5}$ \\ ${ }^{1}$ M.D. Scholar, Department of Panchakarma, Institute for Postgraduate Teaching and Research in Ayurveda, Gujarat \\ Ayurved University, Jamnagar, Gujarat, India \\ ${ }^{2}$ Head, Department of Kaumarbhritya, Institute for Postgraduate Teaching and Research in Ayurveda, Gujarat Ayurved \\ University, Jamnagar, Gujarat, India \\ ${ }^{3}$ Head, Department of Panchakarma, Institute for Postgraduate Teaching and Research in Ayurveda, Gujarat Ayurved \\ University, Jamnagar, Gujarat, India \\ ${ }^{4} \mathrm{Head}$, Pharmacognosy, Institute for Postgraduate Teaching and Research in Ayurveda, Gujarat Ayurved \\ University, Jamnagar, Gujarat, India \\ ${ }^{5}$ Head, Pharmaceutical Chemistry Lab, Institute for Postgraduate Teaching and Research in Ayurveda, Gujarat Ayurved \\ University, Jamnagar, Gujarat, India
}

Received on: 25/06/17 Accepted on: 20/11/17

\begin{abstract}
*Corresponding author
E-mail: drsurendra87@gmail.com
\end{abstract}

DOI: $10.7897 / 2277-4343.086293$

\begin{abstract}
The Vajigandhadi Basti has been mentioned specifically for Gridhrasi (Sciatica) in Yogarathnakara Vatavyadi Chikitsa Adhikarana. Niruha is the one type of Basti (medicated enema) containing Kwatha (decoction of herbal drugs) as the chief constituent along with Madhu (honey), Saindhava (rock salt), Kalka (paste of herbs) and Sneha (oil). In Vajigandhadi Niruha Basti (VNB) Vajigandhadi Kwatha (decoction), Putoyavani Kalka (paste) and Vajigandhadi Taila (oil) are being used. The prepared VNB medicament subjected to physico-chemical and chromatographical parameters for standardization. Pharmacognostical identified features of coarse powder were systemically explained and physicochemical findings of prepared Basti such as specific Gravity, total solid contents, $\mathrm{pH}$ value were found to be $1.0390,23.82 \% \mathrm{gm} / \mathrm{ml}$, and $5.5 \mathrm{respectively}$. The chromatographic authentication of prepared VNB was done under pre-chromatographic derivatization technique. Microscopic characteristics like the border pitted vessels, stellete trichome, scleroid, oil globules, rhomboidal crystal, starch grains, prismatic crystals, annular vessel, black debris etc. showed the presence of mentioned ingredients in prepared VNB. The findings from this study will provide systemic evaluation and also encouraging towards the goal for standardizing VNB.
\end{abstract}

Key words: Chromatography, Gridhrasi, Pharmacognosy, Vajigandhadi Niruha Basti.

\section{INTRODUCTION}

Sciatica is a benign syndrome characterized especially by pain starting from the lumbar region and radiating down towards the lower limb. Ayurveda had identified this problem long back and named it 'Gridhrasi'. The word 'Gridhrasi' itself suggests the gait of the patient similar to Gridhra (vulture) due to pain ${ }^{1}$. Gridhrasi comes under 80types of NanatmajaVatavyadhis ${ }^{2}$. Basti has been glorified as the definitive therapy to subtle the aggravated Vata and Vata Pradhan Vyadhis ${ }^{3}$. Acharya Charaka has mentioned Basti as a procedure in which the drugs that are being administered through rectal route, reach up to the Nabhi (Umbilical region), Kati (Lumber region), Parshva (Loin region) and Kukshi Pradesha (Abdomen), churn the accumulated Purisha and Dosha, spread the unctuousness (potency of the drugs) all over the body and easily come out along with churned Purisha and Doshas ${ }^{4}$. On the other hand standardization point of view to achieve quality of finished product entirely depends on the quality of the raw materials. Therefore, first step of standardization is the quality control aspects of raw material. It can be achieved by macroscopic and microscopic examination of the crude drugs. Preparing the VNB formulation with standard operating procedure which followed by Charak Samhita as SOS approach successfully. Another way the Vajigandhadi Taila has been mentioned in Yogarathnakara Vatavyadi Chikitsa Adhikarana, specifically indicated only for Gridhrasi and the form of administration has been told as Snehapana and Basti ${ }^{5}$. For standardization point view this (VNB) have no valid document is not published. An unorthodox way a preliminary physicochemical analysis of Gokshura Punarnava Basti has been published $^{6}$ successfully. Ayurvedic formulation standardization is focused more or less Pharmacopoeial monograph to validate their claim. This study has designed the valid road map for VNB in favour of physico-chemical (Density, Specific gravity, Total solid content and $\mathrm{pH}$.) \& high performance chromatographically profiling. In this way a sustainable identification tool for VNB formulation in context fingerprinting profile \& physico-chemical constant.

\section{AIMS AND OBJECTIVES}

- To identify dried samples of ingredients powder of VNB macroscopically and microscopically.

- To preliminary analyze the prepared VNB by using different physico-chemical parameters.

- To develop the HPTLC fingerprinting profile.

\section{MATERIALS AND METHODS \\ Collection of Raw Drug}

All the raw drugs of VNB were obtained from Pharmacy, Gujarat Ayurved University, Jamnagar, India and all these were identified and authenticated in Pharmacognosy Laboratory, Institute for Postgraduate Teaching and Research in Ayurveda (IPGT \& RA), 
Gujarat Ayurved University, Jamnagar, India. Ingredients of VNB are depicted at [Table 1].

\section{Microscopical evaluation of powdered crude drugs}

Individual ingredient of the respective VNB formulation undertaken for powder-microscopic evaluation in standard operating procedure.

\section{Preparation method of Vajigandhadi Niruha Basti (VNB)}

The VNB was prepared by the classical method ${ }^{7}$ in department of Panchakarma IPGT\&RA, GAU, Jamnagar. Initially honey (50ml) and rock salt $(5 \mathrm{gm})$ were triturated in the Kharal, and then in respected order Vajigandhadi Taila $(100 \mathrm{ml})$ followed by Putoyavani Kalka (20gm) followed by Vajigandhadi Kwatha $(350 \mathrm{ml})$ were added and triturated till it emulsified properly.

Vajigandhadi Taila constituted Aswagandha, Bala, Bilva and Dasamoola (10 drugs as 1part) in equal proportion was prepared with Eranda Taila (Castor oil) base in RS and BK department, IPGT\&RA, GAU, Jamnagar, India. The Vajigandhadi Kwatha was prepared with the same drugs i.e. Aswagandha, Bala, Bilva and Dasamoola. These drugs were taken in equal proportion to a total of $175 \mathrm{gm}$ then 8 times water $(1400 \mathrm{ml})$ was being added to Dravya and this mixture was being heated until it became $1 / 4^{\text {th }}$ ( $350 \mathrm{ml})$. The Putoyavani Kalka was prepared by taking Yavani,
Madanphala, Bilwa, Kushatha, Vacha, Shatpushpa, Musta and Pippali in equal proportion. In Vajighandhadi Basti, Kalka Dravya has not been mentioned so, Putoyavani Kalka was taken because as per Acharaya Vagbhatta, If Kalka Dravya has not been mentioned in Basti then Putoyavanyadi Kalka can be taken as universal Kalka ${ }^{8}$.

\section{Physico-chemical study}

The organoleptic and physico-chemical analysis of prepared VNB performed in authentic way according to standard protocol.

\section{HPTLC (High Performance Thin Layer Chromatography) evaluation}

Methanolic extract of VNB was spotted on pre-coated silica gel GF $60_{254}$ aluminium plate as $6 \mathrm{~mm}$ bands, $10 \mathrm{~mm}$ apart and 10 $\mathrm{mm}$ edge of the plates, by means of a CAMAG Linomat $\mathrm{V}$ sample applicator fitted with a $100 \mu \mathrm{L}$ Hamilton syringe. Toluene: Ethyl acetate: Acetic acid $(7: 2: 1) 10 \mathrm{ml}$ combination was used as a mobile phase. The development distance was $7 \mathrm{~cm}$ and development time was 30min. After development, Densitometry scanning was performed with a CAMAG TLC scanner III in reflectance absorbance mode at $254 \mathrm{~nm}$ and $366 \mathrm{~nm}$ under control of Win CATS software (V1.3.4 CAMAG).

Table 1: Ingredients of Vajigandhadi Niruha Basti (VNB)

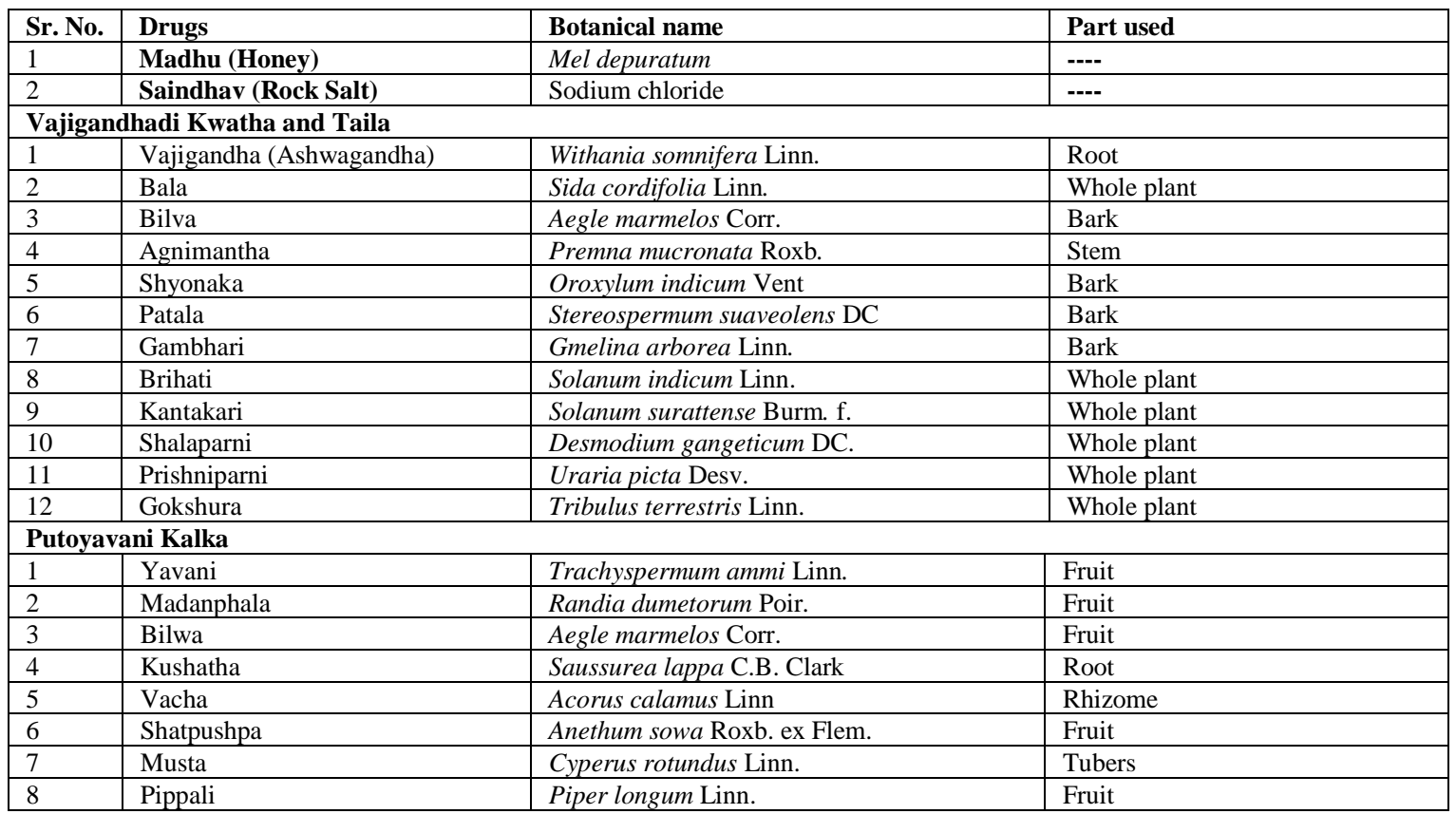

Table 2: Identified Microscopic Characters of Ingredients of Vajigandhadi Kwatha and Taila

\begin{tabular}{|l|l|l|l|}
\hline Drugs & Identified Microscopic Characters & Drugs & Identified Microscopic Characters \\
\hline $\begin{array}{l}\text { Vajigandha } \\
\text { Ashwagandha) }\end{array}$ & Cork cells, Border Pitted Vessels, Starch Grains & Gambhari & Stone cells, Border pitted vessels \\
\hline Bala & $\begin{array}{l}\text { Stellete Trichome, Oil glouble, Romboidal } \\
\text { Crystal, }\end{array}$ & Brihati & $\begin{array}{l}\text { Stone cells, Pitted vessel with Starch Grains, } \\
\text { Simple trichome }\end{array}$ \\
\hline Bilva & $\begin{array}{l}\text { Simple \&compound starch, Fibre with crystal, } \\
\text { Scleroid, }\end{array}$ & Kantakari & $\begin{array}{l}\text { Stone cells, Multi branch Trichome with } \\
\text { Fibers }\end{array}$ \\
\hline Agnimantha & Cork cells, Rhomboidal crystal & Shalaparni & $\begin{array}{l}\text { Trichome, Pitted \& Annular vessel, } \\
\text { Epidermal cells }\end{array}$ \\
\hline Shyonaka & Pitted stone cells, Cigar shaped crystals & Prishniparni & Spiral vessels, Prismatic crystal \& cork cells \\
\hline Patala & Prismatic crystals, Crystal fibres & Gokshura & Prismatic crystals, Epidermal cells \\
\hline
\end{tabular}


Table 3: Identified Microscopic Characters of Ingredients of Putoyavani Kalka

\begin{tabular}{|l|l|}
\hline Ingredients & Identified Microscopic Characters \\
\hline Yavani & Brown content, Annular vessel, Endosperm \\
\hline Madanphala & Group of Stone Cells, Epicarp Cells, Mesocarp cells \\
\hline Bilwa & Simple \& compound starch, Fiber with crystal, Pitted stone cells \\
\hline Kushatha & Spiral vessel \\
\hline Vacha & Scleriform vessel, Starch grains \\
\hline Shatpushpa & Oil Globules \\
\hline Musta & Lignified Fibre, Prismatic crystals, Oleoresin \\
\hline Pippali & Brown content, Black debris \\
\hline
\end{tabular}

Table 4: Organoleptic characters of Prepared Vajigandhadi Niruha Basti

\begin{tabular}{|l|l|}
\hline Parameter Studied & Observations \\
\hline Colour & Dull Brown \\
\hline Odour & Offensive \\
\hline Consistency & Slightly thick Liquid \\
\hline
\end{tabular}

Table 5: Physico-chemical parameters of Vajigandhadi Niruha Basti (VNB)

\begin{tabular}{|l|l|}
\hline Parameter studied & Results DROP \\
\hline Density & $1.1874 \mathrm{w} / 1 \mathrm{gm} / \mathrm{ml}$ \\
\hline Specific gravity & 1.0390 \\
\hline Total solid contents & $23.82 \%$ \\
\hline $\mathrm{pH}$ (By pH strip) & 5.5 \\
\hline
\end{tabular}

Table 6: $\mathbf{R}_{\mathrm{f}}$ values of Prepared Vajigandhadi Niruha Basti (VNB)

\begin{tabular}{|l|l|l|l|l|}
\hline Sample & \multicolumn{2}{|l|}{$\begin{array}{l}\text { Visualize under short UV } \\
(\mathbf{2 5 4} \mathbf{~ n m})\end{array}$} & \multicolumn{2}{l}{$\begin{array}{l}\text { Visualize under short UV } \\
\mathbf{( 3 6 6} \mathbf{~ n m})\end{array}$} \\
\hline $\begin{array}{l}\text { Vajigandhadi } \\
\text { Niruha Basti }\end{array}$ & No. of spots & $\mathrm{R}_{\mathrm{f}}$ value & No. of spots & $\mathrm{R}_{\mathrm{f}}$ value \\
\cline { 2 - 5 } & 8 & $0.03,0.16,0.37,0.55,0.65,0.76,0.78,0.95$ & 8 & $0.02,0.36,0.37,0.53,0.56,0.65,0.76,0.95$ \\
\hline
\end{tabular}

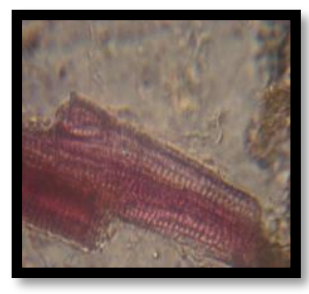

Border Pitted Vessels (Ashwagandha)

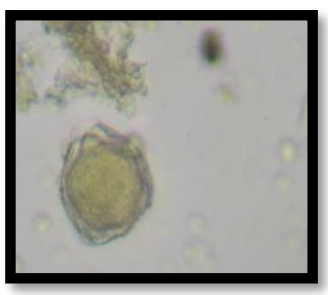

Oil globule (Bala)

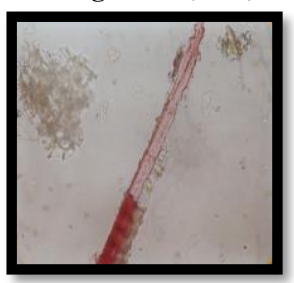

Fibre with crystal (Bilwa)

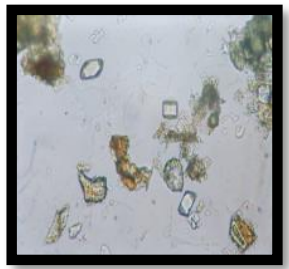

Rhomboidal crystal (Agnimantha)

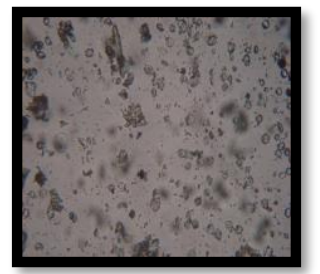

Starch Grains (Ashwagandha)

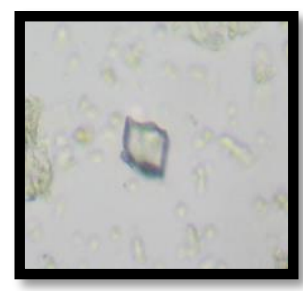

Rhomboidal crystal (Bala)

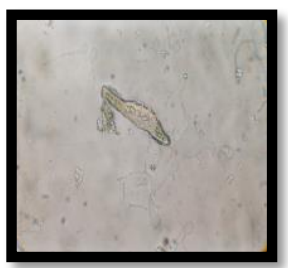

Scleroid (Bilwa)

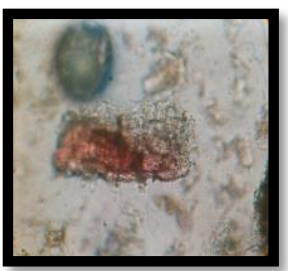

Cork cells (Agnimantha)

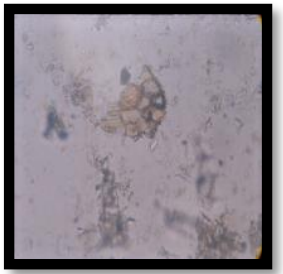

Cork cells (Ashwagandha)

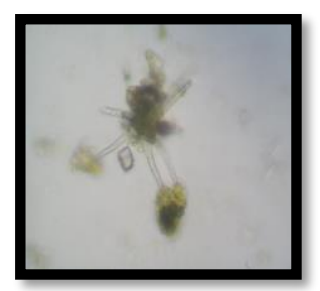

Stellate trichome (Bala)

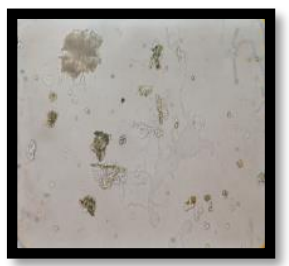

Starch simple \& compound (Bilwa)

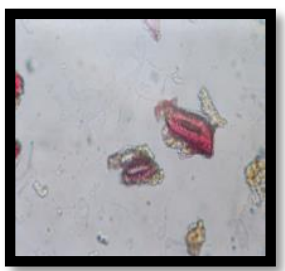

Stone cells (Agnimantha) 


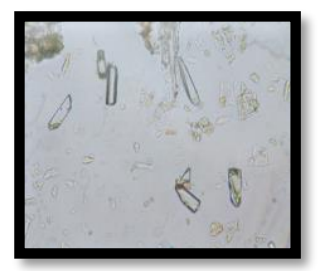

Cigar shaped crystal (Syonaka)

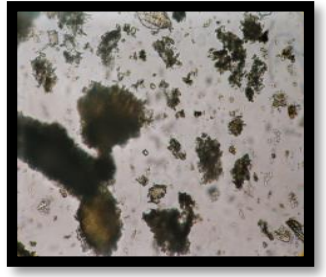

Prismatic crystal (Patala)

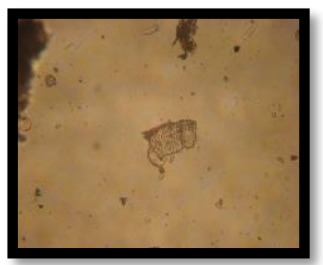

Pitted vessels with starch grains (Brihati)

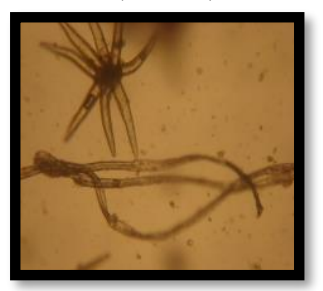

Multi branch trichome with fibres (Kantakari)

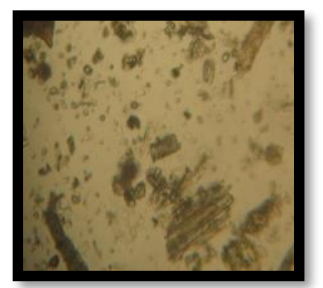

Spiral vessels (Prishniparni)

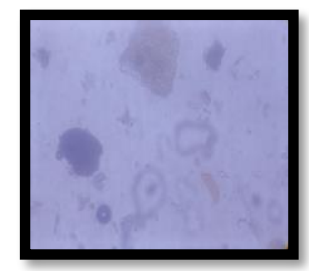

Epidermal cells (Shalaparni)

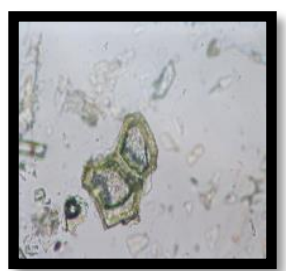

Pitted stone cell (Syonaka)

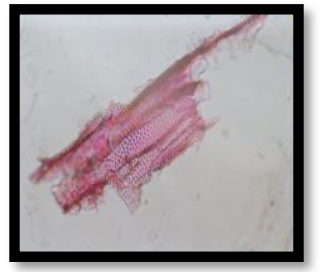

Border pitted vessels (Gambhari)

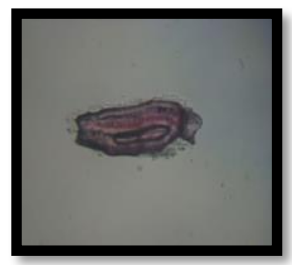

Stone cells (Brihati)

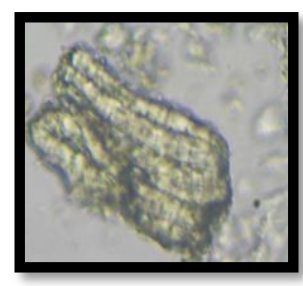

Stone cells (Kantakari)

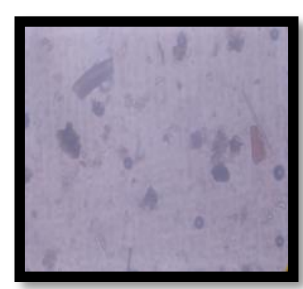

Pitted \& Annular vessels (Shalaparni)

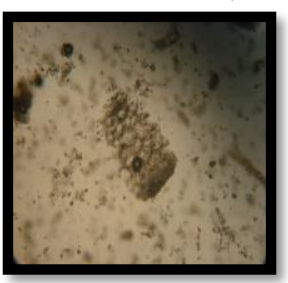

Epidermal cells (Gokshura)

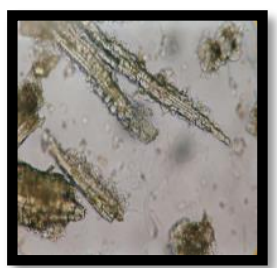

Crystal fibres (Patala)

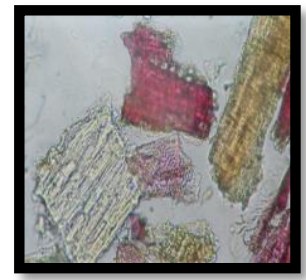

Stone cells (Gambhari)

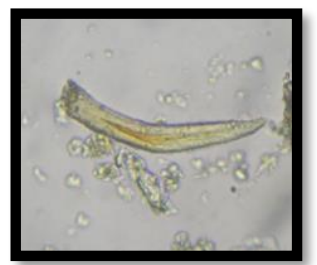

Simple trichome (Brihati)

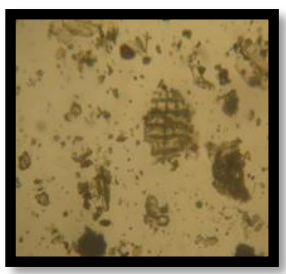

Prismatic crystal \& cork cells (Prishniparni)

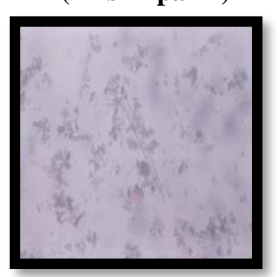

Trichome (Shalaparni)

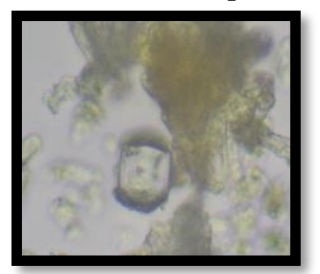

Prismatic crystals (Gokshura)

Plate 1 - Microphotographs of Vajigandhadi Kwatha and Taila Ingredients 


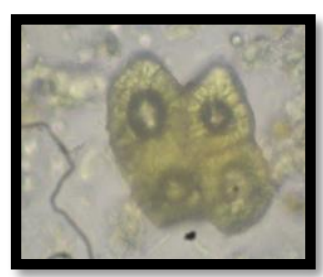

Group of Stone Cells (Madanaphala)

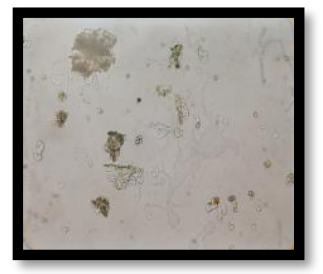

Simple \& compound starch (Bilva)

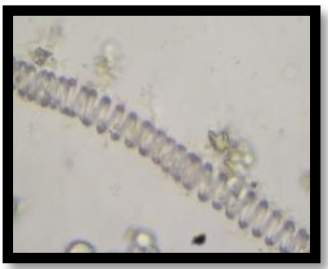

Spiral vessel (Kushtha)

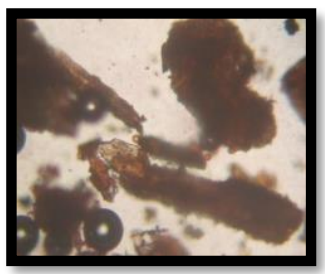

Oil Globules (Shatpushpa)

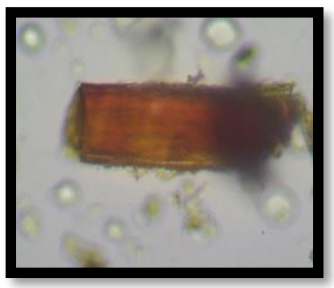

Oleoresin (Musta)

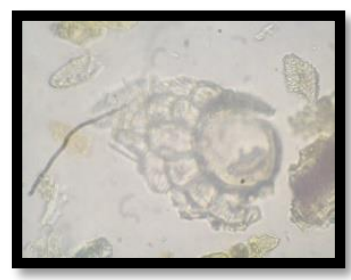

Endosperm (Yavani)

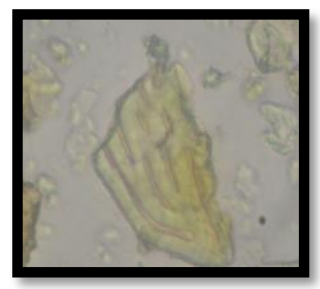

Epicarp cells (Madanaphala)

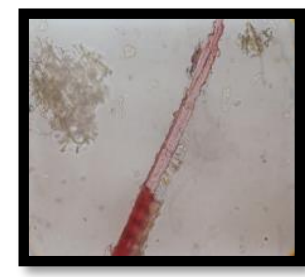

Fibre with crystal (Bilva)

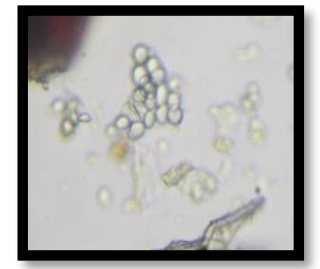

Starch grains(Vacha)

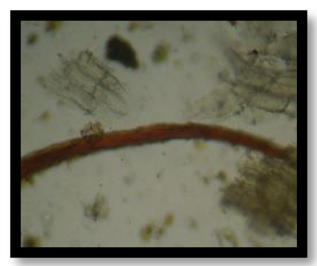

Lignified Fibre (Musta)

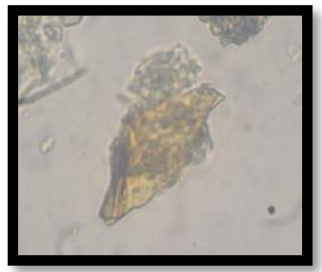

Brown content (Yavani)

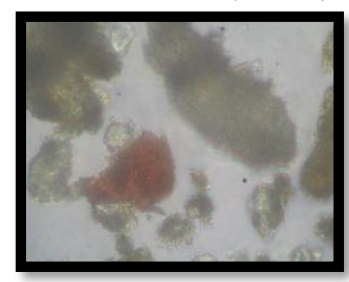

Brown content (Pippali)

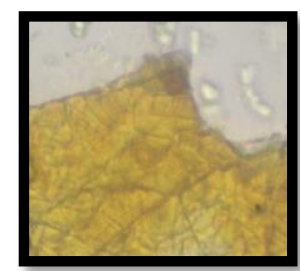

Mesocarp Cells (Madanaphala)

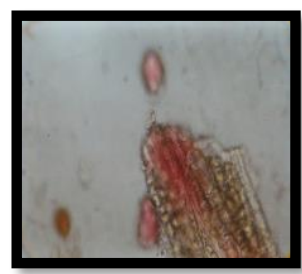

Pitted stone cell (Bilva)

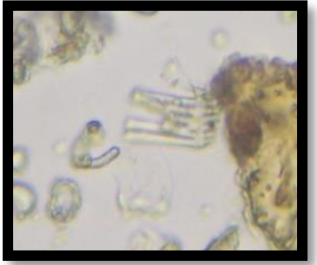

Scleriform vessel (Vacha)

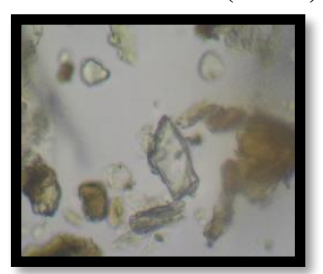

Prismatic crystals (Musta)

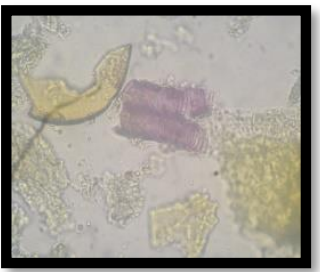

Annular vessel (Yavani)

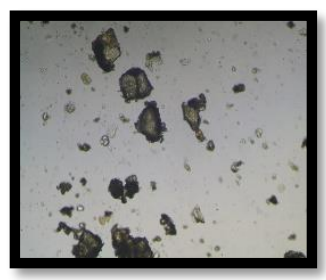

Black debris (Pippali)

Plate 2: Microphotographs of Putoyavani Kalka Ingredients 


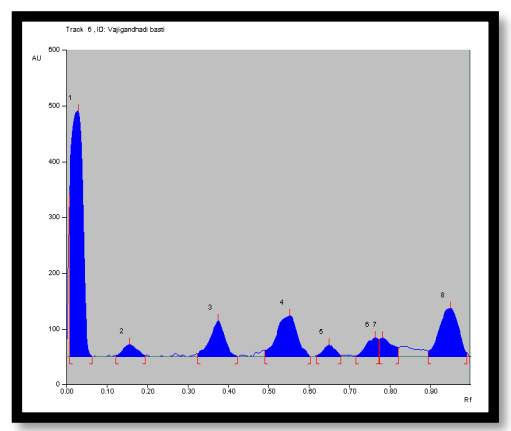

At 254nm

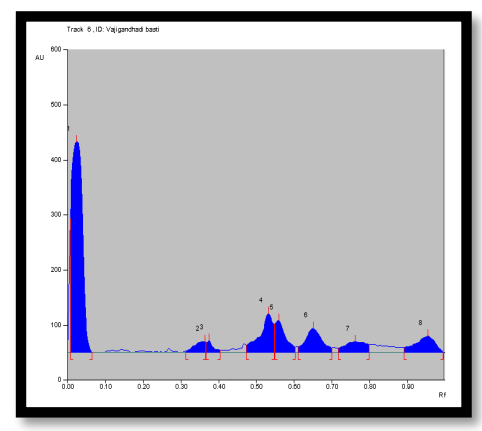

At 366nm

Plate 3: Densitogram of Prepared Vajigandhadi Niruha Basti (VNB) at $254 \mathrm{~nm}$ and 366nm

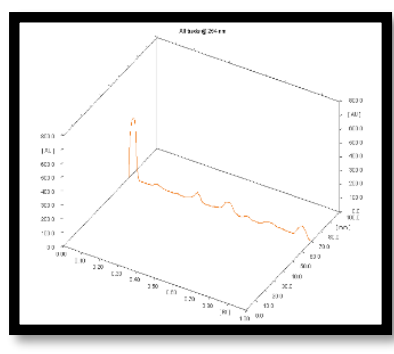

At 254nm

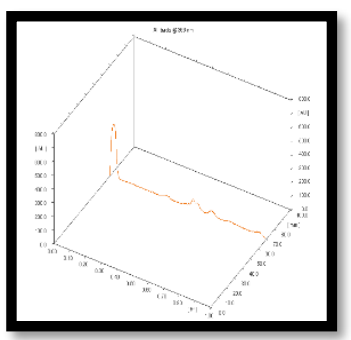

At 366nm

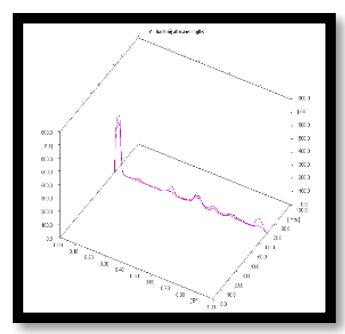

Comparison at $254 \mathrm{~nm} \& 366 \mathrm{~nm}$

Plate 4: Three dimensional (3D) Densitogram of prepared Vajigandhadi Niruha Basti (VNB) at 254nm, 366nm \& Comparison at 254nm \& $366 \mathrm{~nm}$
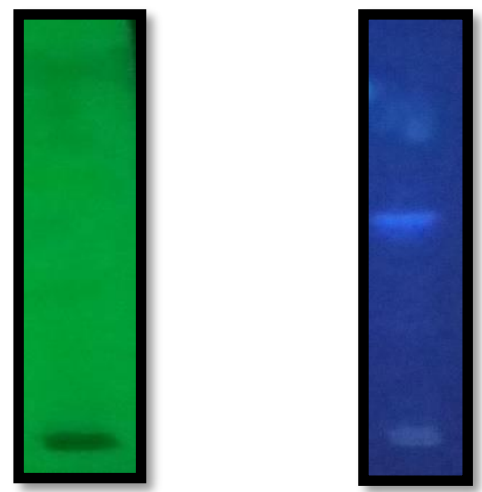

Plate 5: HPTLC finger prints of prepared Vajigandhadi Niruha Basti (VNB) at 254nm and 366nm (Fig. a, b)

(a) At $254 \mathrm{~nm}$

(b) At 366nm

\section{RESULTS AND DISCUSSION \\ Microscopic Characters}

Powder of the ingredients of Putoyavani Kalka, Vajigandhadi Taila and Kwatha were studied microscopically. The powder of the drug was dissolved with water. Then microscopy of the sample was done without stain and after staining with Phloroglucinol + $\mathrm{HCl}$. The identified powder microscopic characters are placed at respective table [Table $2 \& 3$ ] and microphotographs are placed at respective plate [Plate 1\&2]. All identified microscopic characteristics were equivalent to standard profile.

\section{Organoleptic characters of prepared VNB}

Prepared VNB was dull brown in colour, slightly thick in consistency and had offensive odour [Table 4].

\section{Physico-chemical parameters}

The prepared VNB was evaluated for various physico-chemical parameters like Density, Specific gravity, Total solid content and $\mathrm{pH}$. The observed results are placed at Table 5. Density and specific gravity and $\mathrm{pH}$ is directly reflect the formulation stability condition. Total solid content revealed the dissolved materials in water (such as potassium, sodium etc.) moderate quantity to maintain the formulation status in favour of physico-chemical constant.

\section{HPTLC (High Performance Thin Layer Chromatography)} evaluation

In this study VNB is well separated compact symmetrical bands in favour of chromophore sensitive component (Polyphenol, Flavonoid and quaternary alkaloids). This bio-ligand are responsible for formulation promising development condition. 
HPTLC of VNB visualized under short UV $(254 \mathrm{~nm})$ showed 8 spots at $0.03,0.16,0.37,0.55,0.65,0.76,0.78,0.95 \mathrm{R}_{\mathrm{f}}$ while under long UV (366nm) showed 8 spots at $0.02,0.36,0.37,0.53$, $0.56,0.65,0.76,0.95 \mathrm{R}_{\mathrm{f}}$ [Table 5/Plate 3 \& 4]. Component represent by the $\mathrm{R}_{\mathrm{f}} 0.55,0.65,0.76$ and 0.95 were common in both light exposure. The fingerprinting profile exemplified as an herb-print of this formulation.

\section{CONCLUSION}

The present study was aimed to analyze the physico-chemical parameters of Basti form and also to develop HPTLC profile of VNB. The separation pattern of VNB is documented with help of prechromatographic derivative method in context of $R_{f} \&$ densitogram. The Pharmacognostical evolution proved that ingredients were present in VNB. The VNB was found to be significant based on physico-chemical parameters. The findings from this study will provide systemic evaluation and shall also be encouraging towards the goal for standardization of VNB formulation. The study results may be used as the reference standard in further research undertakings of its kind.

\section{ACKNOWLEDGEMENT}

The author wishes to thank the Jayanta Kumar Maji, PhD Scholar (Pharmaceutical Chemistry), IPGT\&RA for his sincere support throughout this work.

\section{REFERENCES}

1. Raja Radhakanta Dev, Shabdakalpadruma, Vol-2, $3^{\text {rd }}$ ed. Choukambha Ayurved Pratisthan, Varanasi, 2006:p348

2. Agnivesha, Charaka Samhita with Charaka Chandrika Hindi Commentary by Dr. Brahmanand Tripathi, Part $1^{\text {st }}$,
Sutrasthana 20/11, $1^{\text {st }}$ ed. (reprint), Varanasi: Chaukhambha Krishnadas Academy; 2009:p389

3. Vruddha Vagabhata, Asthang samgraha with sasilekha commentary by Indu, edited by Dr. shivaprasad sharma, Sutrasthana 28/12, Varanasi: Chaukhambha Krishnadas Academy; 2008;p214

4. Agnivesha, Charaka Samhita with Charaka Chandrika Hindi Commentary by Dr. Brahmanand Tripathi, Part $2^{\text {nd }}$, Siddhisthana $1 / 40,1^{\text {st }}$ ed. (reprint), Varanasi: Chaukhambha Krishnadas Academy;2009:p1170

5. Vaidya Sri Lakshmipathi sashtri-Yogarathnakara-Vidyothini Hindi Teeka.Edited by Bhishagratna Brahmasankar Shastri, Chaukamba publications, Varanasi, $7^{\text {th }}$ ed., Vatavyadhi chikita, 1999:p522

6. Ramteke Rajkala, Thakar AB, Shukla VJ, Harisha CR. A preliminary physico-chemical assay of Gokshura-Punarnava Basti - A pilot study, Int. J. Res. Ayurveda Pharm. 2011, 2(2) 343-349. Available online through www.ijrap.net/admin/php/uploads/420_pdf.pdf

7. Agnivesha, Charaka Samhita with Charaka Chandrika Hindi Commentary by Dr. Brahmanand Tripathi, Part $2^{\text {nd }}$, Siddhisthana 3/23-24, $1^{\text {st }}$ ed. (reprint), Varanasi: Chaukhambha Krishnadas Academy;2009:p1197

8. Astanga Hrudayam, Vidvanmanoranjini hindi commentary by Kasinath shastri, $1^{\text {st }}$ ed., kalpasthana 4/2-3 Chaukhamba Sanskrit pratishthan, 1994:p373

\section{Cite this article as:}

Surendra Kumar et al. A preliminary physico-chemical assay of vajigandhadi niruha basti. Int. J. Res. Ayurveda Pharm. 2017;8(6):58-64 http://dx.doi.org/10.7897/2277-4343.086293

\section{Source of support: Nil, Conflict of interest: None Declared}

Disclaimer: IJRAP is solely owned by Moksha Publishing House - A non-profit publishing house, dedicated to publish quality research, while every effort has been taken to verify the accuracy of the content published in our Journal. IJRAP cannot accept any responsibility or liability for the site content and articles published. The views expressed in articles by our contributing authors are not necessarily those of IJRAP editor or editorial board members. 